\title{
DIFFERENCES IN TEMPERATURE REGIME OF MINERAL AND PEAT SOIL IN BAKCHAR DISTRICT OF TOMSK REGION
}

\author{
E.A. Dyukarev ${ }^{1,2}$, A.A. Vyaizya ${ }^{3}$, M.V. Kiselev $^{1}$ \\ ${ }^{1}$ Institute of Monitoring of Climatic and Ecological Systems of the Siberian Branch of the Russian Academy \\ of Sciences, Tomsk, Russia \\ 2 Yugra State University, Khanty-Mansiysk, Russia \\ 3 Tomsk State University, Russia \\ Автор для переписки: dekot@mail.ru
}

Citation: Dyukarev EA, Vyaizya AA, Kiselev MV, 2019. Differences in temperature regime of peat and mineral soil at Bakchar district of Tomsk region. Environmental dynamics and global climate change. 100-109. https://doi.org/10.17816/edgcc21323

The results of long-term monitoring of soil temperature regime at Bakchar district (Tomsk region) located in the southern taiga zone of Western Siberia are presented. The temperature regimes of peat and mineral soils are compared; their difference is shown. Peat soil has a smoothed temperature dynamics compared to mineral soil. According to monthly average data, in the warm season, the upper $80 \mathrm{~cm}$ of peat soil is $5-7^{\circ} \mathrm{C}$ colder than the mineral soil and $0.3-1.0^{\circ} \mathrm{C}$ warmer in the cold season. The increased thermal inertia of the peat soil prevents both its heating and cooling.

Key words: soil temperature, Western Siberia, oligotrophic mire, mineral soil, peat soil

Представлены результаты многолетнего мониторинга температуры почв Бакчарского района (Томской области), расположенного в зоне южной тайги Западной Сибири. Проведено сравнение температурных режимов торфяной почвы и минеральной, показано их отличие. Торфяная почва имеет сглаженную динамику температуры по сравнению с минеральной. По средним месячным данным в теплое время года верхние 80 см торфяной почвы холоднее минеральной на $5-7^{\circ} \mathrm{C}$, а в холодное время - теплее на $0,3-1,0{ }^{\circ} \mathrm{C}$. Повышенная тепловая инерция торфяной толщи препятствует как ее нагреву, так и охлаждению.

Ключевые слова: температура почвы, Западная Сибирь, олиготрофное болото, минеральная почва, торфяная почва

\section{BBEQEEHИE}

Болота - уникальные природные ландшафты, участвующие в регулировании газового состава атмосферы, водного баланса биосферы и биологического разнообразия [Доктуровский, 1932; Лисс и др., 2001; Barid et al., 2013]. Торфяные болота являются наиболее значимым на суше долговременным накопителем атмосферного углерода [Иванов, Новиков 1976; Вомперский и др., 2005; Rydin, Jeglum, 2015]. Температура почвы является ключевым фактором, контролирующим многие биотические и абиотические процессы, протекающие в почвах (торфяных и минеральных): разложение и минерализацию органического вешества почв, эмиссию парниковых газов, выделение растворенного органического углерода; воздействует на рост наземной растительности (мхи, кустарники и др.) и формирование микроклимата [Марчик и Ефремов, 2006].

Почвы являются одним из главных источников $\mathrm{CO}_{2}, \mathrm{CH}_{4}$ и $\mathrm{N}_{2} \mathrm{O}$, увеличивающаяся атмосферная концентрация которых относится к числу наиболее широко обсуждаемых, но пока недостаточно изученных причин климатических изменений [IPCC, 2013; Второй оценочный доклад..., 2014; Парниковые газы являются продуктами метаболизма микробов, который регулируется температурой. Потепление климата приводит к изменению термического режима торфяных и минеральных почв и динамики их промерзания [Павлов, 2008; Шерстюков, Шерстюков, 2015; Peng et al., 2017] изменению дат установления и разрушения снежного покрова [Осокин, Сосновский, 2014; Дюкарев, 2015; Zhong et al., 2018], а также к изменению снегонакопления [Павлов, 2008; Китаев, Кислов, 2008].

Тепловые режимы торфяных и минеральных почв существенно различаются [Чечкин, 1970; Иванов, Новиков 1976; Гиличинский, 1986; Геокриология СССР, 1989; Основы геокриологии, 2001; Дюкарев и др., 2009; Трофимова, Балыбина, 2015]. Торфяные почвы характеризуются наличием поверхностного торфяного горизонта, сменяющегося органогенной породой [Классификация..., 2004]. Общая мощность 
торфяной толщи может достигать нескольких метров. Торфяная толща представляет собой сложную органоминеральную систему, обладающую специфическими свойствами: высокой обводненностью и пористостью, содержанием большого количества малоразложившегося органического вещества [Романов, 1961; Чечкин, 1970]. Температуропроводность органического вещества торфа на порядок меньше, чем у типичных минералов почвы. Высокое содержание органики в почве увеличивает ее пористость, что также снижает теплопроводность почвы, особенно когда поры заполнены воздухом [Романов, 1961; Иванов, Новиков 1976]. Грубый органический материал, состоящий из остатков сфагновых мхов разной степени разложения действует как теплоизолятор, и его присутствие охлаждает почву летом, в то время как его согревающий эффект зимой менее важен из-за изолирующего влияния снежного покрова [Дюкарев, Головацкая 2013; Kiselev et al., 2019]. Наличие пористого теплоизолирующего слоя в летнее время, в свою очередь, сдерживает микробное разложение и способствует накоплению еще большего объема органики. Учитывая высокое содержание органического вещества в торфяных почвах и высокую уязвимость и чувствительность этих запасов углерода к прогнозируемому потеплению, важно оценить существующие разности в температурах торфяных и минеральных почв, находящихся в одинаковых климатических условиях.

Для болот Западной Сибири характерно относительно неглубокое промерзание почв, и увеличение глубины промерзания здесь сопровождается существенным запаздыванием сроков полного оттаивания почв по сравнению с минеральными почвами [Иванов, Новиков 1976; Чигир, 1978]. В песках отмечается наибольшая глубина промерзания (до 2.5-3.0 м) [Геокриология СССР, 1989]. Суглинки на залесенных территориях промерзают не глубже 1.0-1.8 м. Торфяный горизонт промерзает в основном на глубину 0.3-0.9 м. На многих заносимых снегом участках болот среди лесов в некоторые зимы водонасыщенный торф не промерзает совсем [Геокриология СССР, 1989]. Первые работы по изучению промерзания болот [Серебрянская, 1946] в Барабинской низменности показали, что из-за неоднородности мезорельефа болотных массивов и разной высоты снежного покрова глубина промерзания варьирует от 50-70 см на верховых болотах, и 50-90 см в низинных болотах, до 76-102 см под гипново-осоково-мочажинными и осоково-гипновыми комплексами [Чечкин, 1970]. Толщина мерзлого слоя неосушенных болот севера европейской территории России варьирует от 24 см в зоне евтрофных и олиготрофных сосново-сфагновых торфяников до 62 см в провинции крупнобугристых торфяников Северной Колы [Чечкин, 1970]. В период с 1966 по 2012 гг. в среднем на территории Северной Евразии наблюдается увеличение высоты снежного покрова в зимние и весенние месяцы и ее уменьшение осенью [Zhong et al., 2018], что, безусловно, оказывает воздействие на динамику сезонно-мерзлого слоя. В ответ на наблюдаемое увеличение приземной температуры воздуха средние годовые температуры почв в болотах севера ЕТР в период с 1978 по 2012 гг. увеличиваются со скоростью $0.2-0.9^{\circ} \mathrm{C} / 10$ лет [Калюжный, Батуев, 2015].

На территории нашей страны массовые наблюдения за температурами почв начали проводиться с 1930-х годов и проводятся до сих пор [Наставление..., 1985; Шерстюков, 2008; Трофимова и Шеховцов, 2011]. В настоящее время работы по изучению температурного режима почв продолжаются с использованием современного автоматического оборудования [Воропай и др., 2019; Киселев и др., 2016, 2017; Базаров и др., 2016; Архангельская, 2012; Каверин и др., 2009; Васильев и др., 2008; Сергеев и др., 2007; Константинов и др., 2006 и пр.] Так, в работах [Коронатова 2019; Киселев и др., 2019] и показана значительная вариабельность температурных и мерзлотных режимов торфяных почв, связанная с микрорельефом, от которого зависит уровень стояния болотных вод и перераспределение снежного покрова. На различия в температурном режиме плоскобугристых болотных комплексов значительное влияние оказывают принадлежность к разным болотным экосистемам, биоклиматическим зонам и наличие многолетнемерзлых пород [Коронатова и др. 2018; Махатков, Ермолов, 2015]. Изучение температурного режима болот, находящихся в разных частях Западно-Сибирской равнины (северной, центральной и южной) по материалам наблюдений Западно-Сибирской экспедиции ГГИ [Иванов, Новиков, 1976] показало, что возможно использовать результаты наблюдений на метеостанции для определения температуры на близко расположенном болоте, однако надежные зависимости получены только для среднедекадных значений на глубинах 10-20 см.

Целью данной работы была оценка особенностей температурного режима торфяных почв по сравнению минеральными почвами окружающих территорий, что является важной задачей, поскольку болота на территории Сибири занимают более $30 \%$ площади, но современные оценки изменений температуры почв строятся только по данным имеющейся сети наблюдений на метеостанциях, находящихся преимущественно на минеральных почвах [Харюткина, 
Логинов, 2019; Шерстюков, Шерстюков, 2015]. Ранее нами было выполнено подобное сравнение [Дюкарев, Головацкая, 2013], однако сопоставление проводилось до глубины 80 см и для характеристики температурного режима торфяных и минеральных почв использовались различное оборудование. Данная работа лишена этих недостатков. Сопоставляемые ряды получены с помощью однотипного оборудования, и исследована температура почвы до глубины $240 \mathrm{~cm}$.

Выявление закономерностей функционирования болотных экосистем при изменении климатических условий создает основу для надежных оценок состояния растительности и разнонаправленных потоков углерода. Полученные результаты важны для выявления роли обширных заболоченных территорий Западной Сибири не только в глобальном круговороте углерода, но и в формировании регионального и глобального климата.

\section{TEPPИTOPИЯ ИCCחEGOBAIHЯ}

Исследования температурного режима торфяных почв проводились в Томской области на территории Бакчарского болотного массива (Васюганское болото, 2003), находящегося между реками Бакчар и Икса. Средняя мощность торфа Бакчарского болота 2-2,5 м, с максимумом в 5-6 м. [Исследование природно-климатических процессов ..., 2012]. Пункт мониторинга был оборудован на сосново-кустарничково-сфагновом болоте с угнетенным древесным ярусом на расстоянии около 200 м от окраины болота (56 $58^{`}$ с.ш. $82^{\circ} 36^{\prime}$ в.д.). Почва в пункте мониторинга торфяная олиготрофная, подстилаемая озерно-аллювиальными карбонатными глинами. Мощность торфяной толщи в месте наблюдений составляет 2,2 м. Верховой торф в верхних 1,5 м торфяной залежи представлен двумя видами: фускум слабой степени разложения и магелланикум средней степени разложения. В основании торфяной толщи лежит слой мощностью 30 см хвощевого низинного торфа. Над ним слой осокового низинного торфа. На контакте двух пластов верхового и низинного - располагается слой торфа переходного типа, отложенный когда-то существовавшими здесь мезотрофными растительными сообществами - древесно-осоковым и древесно-сфагновым [Головацкая и др., 2008]. Уровень болотных вод снижается от 5-15 см весенний период до 40-60 см в конце лета. Средняя высота древостоя - 2-3 м, средний диаметр стволов 3 см. Проективное покрытие древесного яруса $30 \%$. Кустарничковый ярус развит обильно на микроповышениях (кочках), общее проективное покрытие - 60-70\%. Ярус сложен багульником болотным, миртом болотным, подбелом, голубикой и клюквой. Травяной ярус имеет проективное покрытие менее $5 \%$ и представлен пушицей влагалищной, морошкой и росянкой круглолистой. В моховом покрове на повышениях доминирует сфагнум бурый (95\%), кроме того, на понижениях встречаются сфагновые топяные мхи.

Пункт мониторинга температурного режима минеральных почв расположен на территории метеостанции, находящейся на окраине райцентра Бакчарского района (с. Бакчар). Наблюдательная площадка метеостанции находится на террасе р. Бакчар на расстоянии около 1 км от реки $57^{\circ} 00^{`}$ с.ш. $82^{\circ} 03^{`}$ в.д.). Почва в месте расположения метеостанции дерновоглеевая тяжелосуглинистая. Уровень грунтовых вод колеблется в диапазоне 20-150 см. Поверхность почвы на метеостанции покрыта травой, регулярно подстригаемой в течение лета в соответствии с требованиями проведения метеорологических наблюдений [Наставление..., 1985].

Исследуемая территория находится в пределах таежной зоны. Климат умеренно-континентальный, отличается значительными суточными и годовыми вариациями температуры воздуха и продолжительным зимним периодом. Среднегодовая температура $+1,8^{\circ} \mathrm{C}$, средняя температура июля $+19,4^{\circ} \mathrm{C}$, средняя температура января $-15,9^{\circ} \mathrm{C}$. Безморозный период составляет 100-105 дней. Сумма годовых осадков - 435 мм [Ландшафты болот ..., 2012].

\section{METO@bI n MATEPИAПbI}

Исследования температурного режима почв проводились с помощью автономного измерителя профиля температуры (АИПТ) [Kiselev et al., 2018; Базаров и др., 2018], который предназначен для автоматической регистрации температуры почвы и накопление данных измерений за длительный промежуток времени. Модификация АИПТ «скрытой установки» используется для «антивандального» размещения на местности, что определяет невозможность использования демаскирующих конструкций: антенн, солнечных батарей и многих типов датчиков. В итоге этих ограничений применяется контроллер с ультрамалым энергопотреблением (питание от батарей); с большой внутренней энергонезависимой памятью измерений; с интерфейсом USB, используя специальный кабель с герметичным разъёмом (чтобы для считывания данных не выкапывать контроллер из земли); с максимальной степенью защиты оболочки прибора IP68 (возможная работа ниже уровня грунтовых вод); с возможностью использова- 


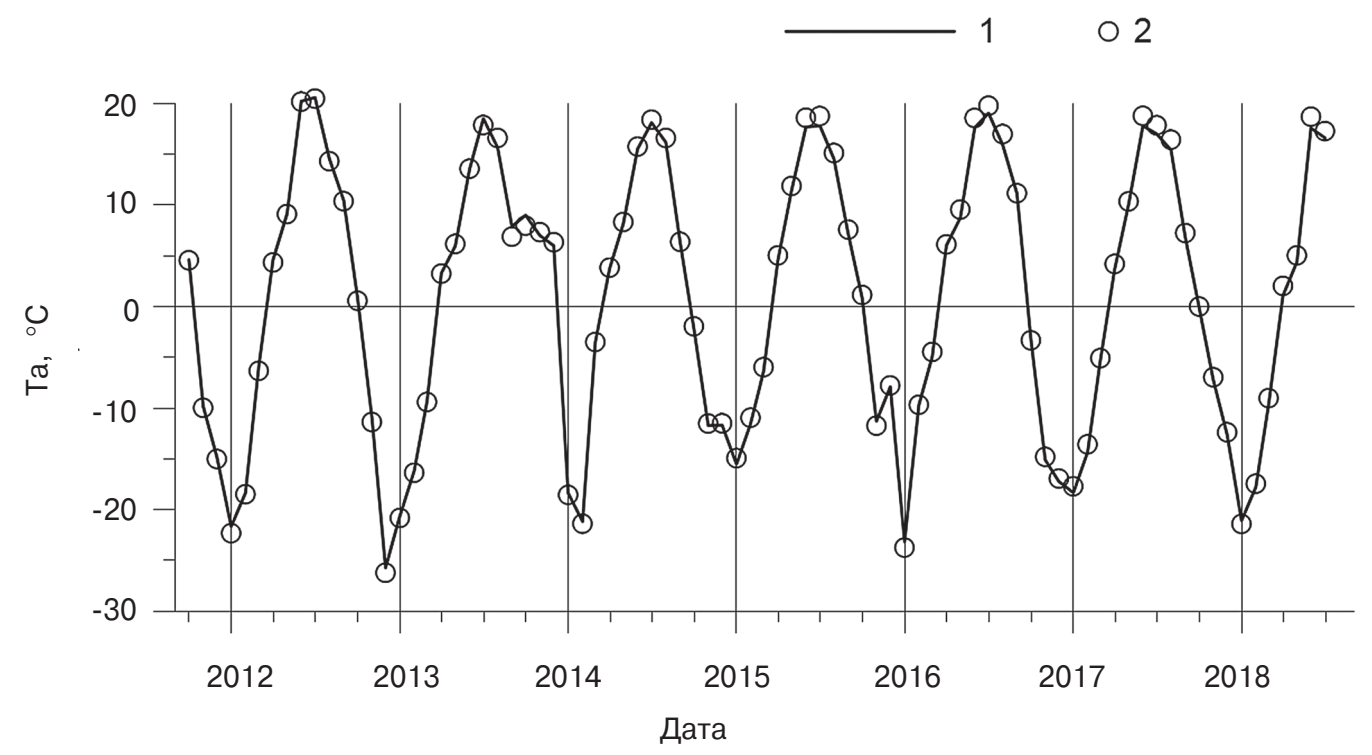

Pnс. 1. Средняя месячная температура воздуха по данным измерений на метеостанции Бакчар (1) и на сосново-кустарничково-сфагновом болоте (2) в 2011-2018 гг.

Fis. 1. The average monthly air temperature according to measurements at the Bakchar weather station (1) and at the pine-shrub-sphagnum bog (2) in 2011-2018

ния датчиков параметров грунта - температуры, влажности, проводимости, а также, уровня воды. А в отдельных случаях и датчиков параметров атмосферы - температуры и влажности.

Два идентичных прибора с датчиками температуры воздуха (на высоте 2 м от поверхности) в радиационной защите и температур почвы были установлены на метеостанции и на болоте. Наблюдения проводились с интервалом 1 час в период с 2011 по 2017 гг. Температура почвы регистрировалась на поверхности и на глубинах 2, 5, 10, 15, 20, 30, 40, 60, 80, 120, $160,240 \mathrm{~cm}$.

\section{PE3YกbTATbI}

По данным наблюдений с помощью АИПТ на метеостанции "Бакчар" среднегодовая многолетняя температура воздуха за исследуемый период с полными годами исследований (20122017 гг.) составляет $+1.1 \pm 1.4{ }^{\circ} \mathrm{C}$ (среднее \pm среднеквадратическое отклонение). Самым холодным месяцем среди всех был декабрь 2012 г., когда среднемесячная температура воздуха достигала $-25,7^{\circ} \mathrm{C}$ (Рис. 1). Самым теплым месяцем был июль 2012 г. с температурой $20,6^{\circ} \mathrm{C}$. Средняя многолетняя температура самого холодного месяца (января) составляет $-19.8 \pm 2.6^{\circ} \mathrm{C}$, а самого теплого (июль) $-+18.2 \pm 1.3{ }^{\circ} \mathrm{C}$, амплитуда годового хода $-39,4 \pm 5.4{ }^{\circ} \mathrm{C}$.

Средняя месячная температура воздуха, рассчитанная по данным измерений аналогичного комплекса АИПТ на сосново-кустарничковосфагновом болоте не существенно отличается от температуры воздуха на метеостанции (см. рис. 1). Разность между месячными температурами воздуха достигает $1.1^{\circ} \mathrm{C}$, причем воздух на болоте теплее, чем на метеостанции. Средняя многолетняя разность температур максимальна в летние месяцы и составляет $0.6,0.4$ и $0.6{ }^{\circ} \mathrm{C}$ для июня, июля и августа, соответственно.

Пункты наблюдений расположены довольно близко друг от друга (на расстоянии 30 км) и значимых различий в многолетнем температурном режиме воздуха между ними нет. Средняя годовая температура воздуха на болоте выше всего лишь на $0.2 \pm 0.3^{\circ} \mathrm{C}$.

Вследствие существующих различий в сложении почвенного профиля и содержании влаги температурный режим почв в пунктах исследований значительно отличается даже несмотря на одинаковое внешнее воздействие (величина приходящей солнечной радиации, режим осадков и пр.). На рисунке 2 приведен временной ход месячных значений температур минеральной и торфяной почвы на некоторых глубинах. Как видим, различия в годовом ходе температуры отмечаются уже на поверхности почвы (Рис. 2a). Зимой под мощным снежным покровом, достигающим 100 см [Дюкарев, 2015], минимальная месячная температура на поверхности почвы на метеостанции не опускается ниже $-2.4{ }^{\circ} \mathrm{C}$ (февраль 2012), а на болоте поверхность может промерзать до $-4.1^{\circ} \mathrm{C}$ (декабрь 2012). Летом максимальная месячная температура поверхности на метеостанции выше $\left(+22.5^{\circ} \mathrm{C}\right.$ в июне 2012), чем на болоте (+19.3 ${ }^{\circ} \mathrm{C}$ в июне 2016). 

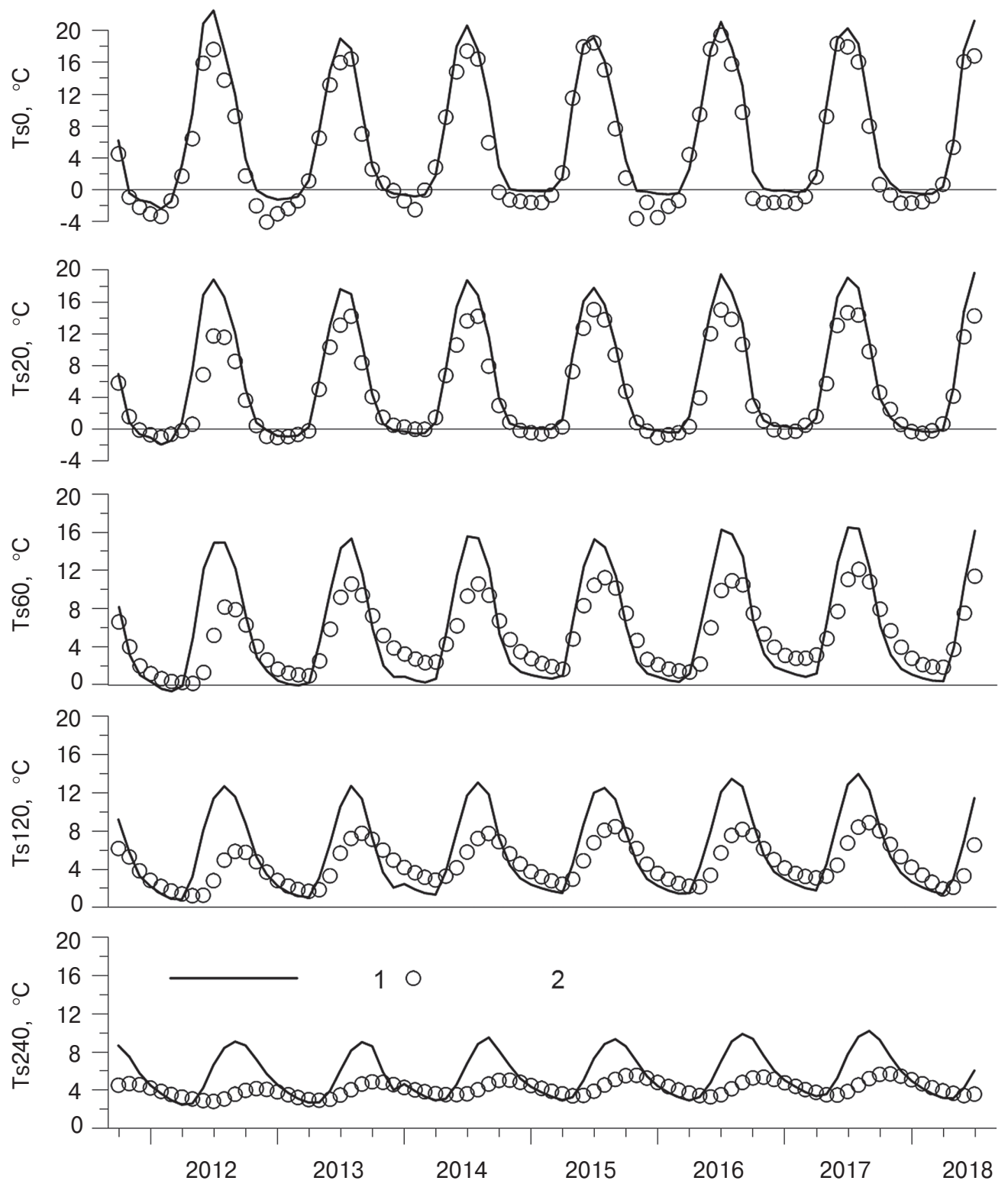

Pnс. 2. Временной ход месячных температур минеральной и торфяной почвы на некоторых глубинах. а - поверхность почвы, б - глубина 20 см, в - 60 см, г - 120 см, д - 240 см. 1 - метеостанция, 2 - болото

Fiळ. 2. Time course of monthly temperatures of mineral and peat soil at certain depths. a - soil surface, $b-$ depth of $20 \mathrm{~cm}, \mathrm{c}-60 \mathrm{~cm}, \mathrm{~d}-120 \mathrm{~cm}$, e $-240 \mathrm{~cm}$. 1 - weather station, $2-$ bog

С глубиной различия в температурном режиме почв между двумя пунктами наблюдений нарастают. Наиболее ярко эти различия проявляются в величине и времени наступления максимальных в годовом ходе температур. Так, на глубине $20 \mathrm{~cm}$ в торфяной почве величина средней июльской температуры на $2.7-7.1^{\circ} \mathrm{C}$ ниже, чем в минеральной. На глубине $60 \mathrm{~cm}$ максимальная в годовом ходе температура в торфяной почве запаздывает приблизительно на месяц относительно максимальной температуры на поверхности, а величина максимума - ниже на $4.0-6.7^{\circ} \mathrm{C}$, по сравнению с температурой поверхности. Глубже разность максимумов не превышает $6.8^{\circ} \mathrm{C}$, а запаздывание относительно поверхности достигает 2-3 месяцев (Рис. 2 г, д).

Менее заметные различия наблюдаются в температурах почвы в холодное время года. До глубины 15-20 см почва на болоте, как правило, холоднее, чем минеральная на $0.1-2.7^{\circ} \mathrm{C}$, и максимальные разности приходятся на поверхностный слой. Глубже 60 см температура торфяной почвы зимой выше, чем минеральной. Наибольшие положительные разности $\left(0.8-2.1^{\circ} \mathrm{C}\right.$ регистрируются на глубине $60 \mathrm{~cm}$. Глубже 60 см (см. рис. 2 г, д) различия в минимальных годовых температурах снижаются до 


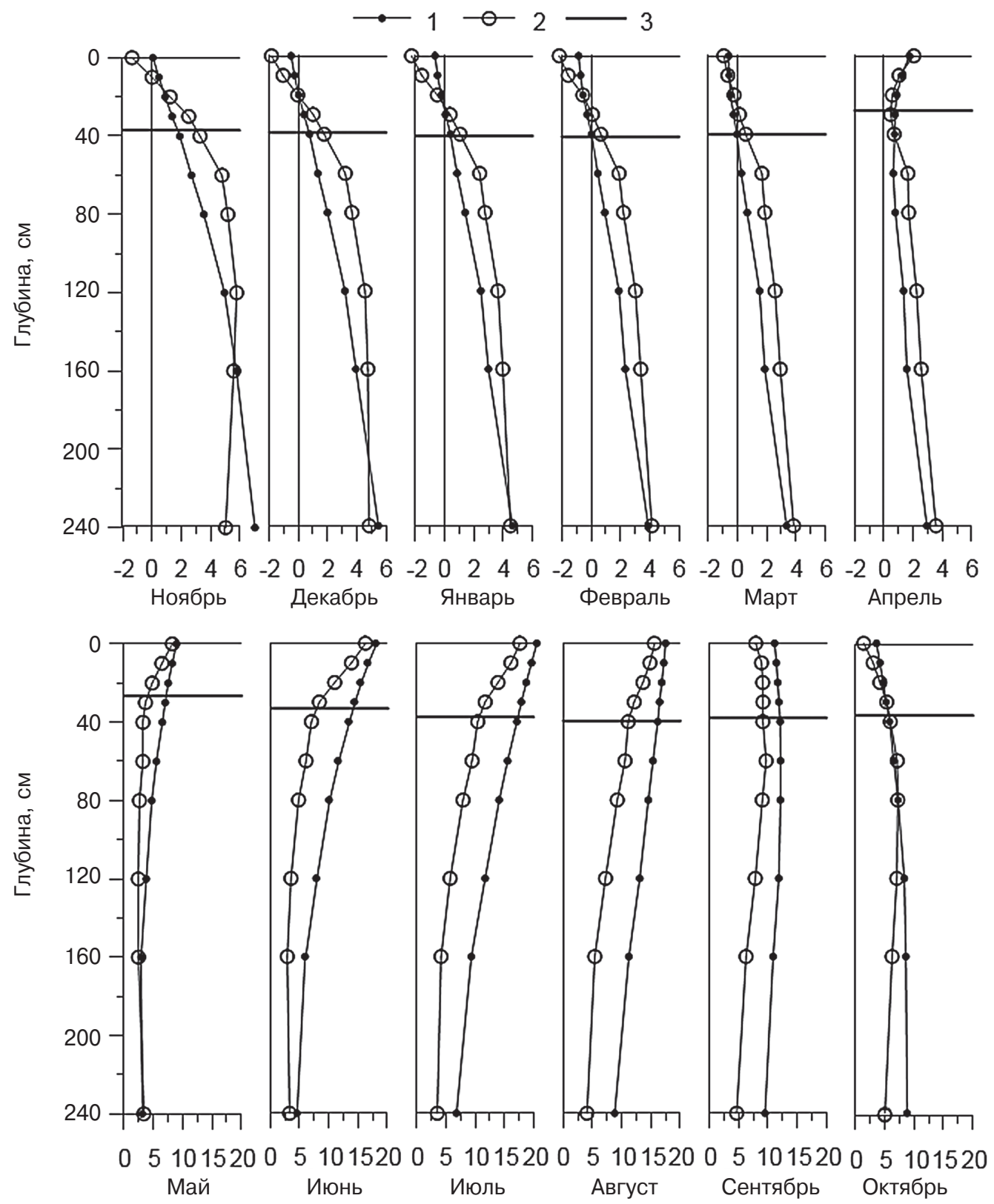

Pnс. 3. Профили распределения средних многолетних месячных температур почвы на метеостанции (1) и болоте (2) за 2011-2017 гг. и средний многолетний уровень воды на сосново-кустарничково-сфагновом болоте (3)

Fiø. 3. Distribution profiles of average long-term monthly soil temperatures at the weather station (1) and the bog (2) for 2011-2017 and the average long-term water level in the pine - shrub-sphagnum bog (3)

$0.1-0.6{ }^{\circ} \mathrm{C}$ на глубине 240 см. Минимальные температуры на болоте наступают позже чем в минеральной почве на 2-3 месяца.

На рисунке 3 показаны средние многолетние профили распределения средних месячных температур почвы на двух пунктах исследований. В холодное время года (с ноября по март) наблюдается радиационный тип распределения температуры в почве [Трофимова и Балыбина, 2015], или увеличение температуры с глубиной. С мая по август температура в верхних слоях почвы выше, чем на глубине, что соответствует инсоляционному типу распределения темпера- туры. Апрель является переходным месяцем с инсоляционно-радиационным температурным режимом, когда в верхнем слое температура с глубиной понижается, а в нижних - незначительно повышается. Сентябрь и октябрь - это месяцы с радиационно-инсоляционным типом распределения температуры.

Средние месячные отрицательные температуры почвы регистрируются с ноября по март на глубинах до 40 см в минеральной почве и до 20 см в торфяной почве. Несмотря на то, что на болоте глубина промерзания меньше, чем на метеостанции, температура верхних слоев 


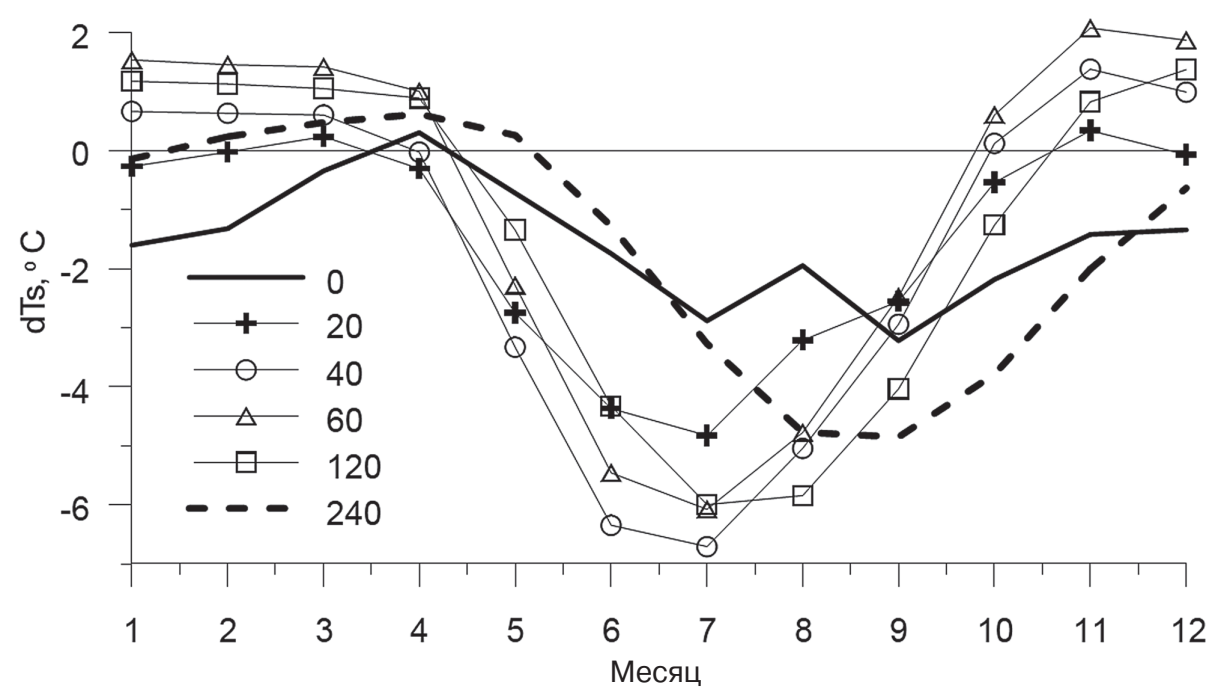

Рис. 4. Разность средних многолетних значений (2011-2018) температуры торфяной и минеральной почвы в различные месяцы

Fis. 4. The difference in the average long-term values (2011-2018) of the temperature of peat and mineral soil in different months

почвы на болоте ниже. Это различие хорошо прослеживается в декабре-феврале на поверхности и глубине 10 см. С ноября по апрель на глубинах между 20 и 160 см торфяная почва теплее минеральной на $0.4-2.1^{\circ} \mathrm{C}$. На наибольшей исследованной глубине (240 см) вследствие запаздывания распространения тепловой волны, температура на болоте лишь немногим (до $0.6{ }^{\circ} \mathrm{C}$ ) выше, чем на метеостанции с февраля по май.

В апреле начинается оттаивание почвы, температура в верхних слоях увеличивается и по всему профилю наблюдаются положительные температуры. В период с мая по сентябрь температура почвы на болоте меньше, чем на метеостанции по всей глубине. Рыхлые слои мохового очеса на болоте, вследствие своей высокой теплоемкости и низкой температуропроводности препятствуют как нагреву, так и охлаждению торфяной почвы, по сравнению с минеральной. Кроме того, на глубине 20-30 см от поверхности в теплое время года располагается верхняя граница болотных вод. На профиле распределения температуры на этой глубине заметен излом и изменение градиента распределения температуры. Большая часть подводимого к этому слою тепла расходуется на испарение влаги. Ниже уровня стояния болотных вод торфяная толща насышена влагой и характеризуется значениями объемной теплоемкости в 1,5-2 раза выше, чем минеральные почвы [12, 13], что так же препятствует проникновению тепла.

Профиль температуры в минеральной почве более чутко откликается на изменения темпе- ратуры на поверхности, градиенты температуры здесь ниже и тепловая волна приникает на большую, чем в торфяной почве глубину. Так, на глубине 240 см, амплитуда годового хода температуры в минеральной почве составляет $6.6 \pm 0.2^{\circ} \mathrm{C}$, а в торфяной почве всего $1.9 \pm 0.3^{\circ} \mathrm{C}$. При том, что годовая амплитуда температуры на поверхности для обеих пунктов наблюдений приблизительно одинакова: $21.4 \pm 1.9^{\circ} \mathrm{C}$ и $21.0 \pm 1.0^{\circ} \mathrm{C}$ для метеостанции и болота, соответственно.

Годовая (с января по декабрь) температура почвы осредненная за полные годы исследований 2012-2017 гг. в минеральной почве плавно снижается от поверхности, где она составляет $6.6 \pm 0.4{ }^{\circ} \mathrm{C}$, до $5.6 \pm 0.1{ }^{\circ} \mathrm{C}$ на глубине $240 \mathrm{~cm}$. В торфяной почве распределение температуры несколько сложнее. От поверхности до глубины 40 см температура так же снижается c $5.1 \pm 0.5^{\circ} \mathrm{C}$ до $4.5 \pm 0.9^{\circ} \mathrm{C}$. Далее на глубине 60 см годовая температура становится равна значениям на поверхности $\left(5.1 \pm 0.5^{\circ} \mathrm{C}\right)$. При увеличении глубины с 60 до 240 см наблюдается дальнейшее уменьшение температуры до $4.1 \pm 0.4{ }^{\circ} \mathrm{C}$. Такой нелинейный характер распределения температуры указывает важность воздействия интенсивных фазовых переходов воды испарения/конденсации на уровне стояния болотных ввод летом (10-50 см) на термодинамические процессы в почве.

Многолетняя средняя годовая температура торфяной почвы на $1.5-1.7^{\circ} \mathrm{C}$ ниже, чем минеральной на глубине до 40 см. Разность температур почвы на болоте и метеостанции на глубине 60 см составляет $1.0^{\circ} \mathrm{C}$, а к глубине 
240 см разность возрастает до $1.6^{\circ} \mathrm{C}$. В целом, почва на болоте холоднее, чем на метеостанции, однако в годовом ходе разность температур почвы между двумя пунктами исследований меняет свой знак.

На рисунке 4 показан годовой ход многолетних средних месячных разностей температуры почвы между торфяной и минеральной почвой. $\mathrm{dTs}=$ Ts (Торф) - Ts (Минер.) Разность температуры поверхности между двумя пунктами исследований практически всегда отрицательная, то есть температура поверхности на болоте ниже, чем на метеостанции. Наибольшая разность температур в $-3.2 \pm 1.1^{\circ} \mathrm{C}$ получена в сентябре. Исключение составляет апрель, когда температура поверхности болота на $0.3 \pm 1.0{ }^{\circ} \mathrm{C}$ выше (Рис. 4).

Отрицательные разности с величиной до $-4.1 \pm 1.2{ }^{\circ} \mathrm{C}$ сохраняются до глубины $15 \mathrm{~cm}$. Однако уже на глубине 20 см в феврале, марте и ноябре температура почвы на болоте немного (до $0.3 \pm 0.5^{\circ} \mathrm{C}$ ) выше, чем на метеостанции. Глубина 40 см характеризуется тем, что здесь наблюдается наибольшая разность температур в летние месяцы. В июне и июле разность температур превышает $-6.0^{\circ} \mathrm{C}$. Существенная отрицательная разность температур (более $-6.0^{\circ} \mathrm{C}$ ) между торфяной и минеральной почвами в июле наблюдается в слое 30-120 см.

Начиная с глубины 40 см непрерывно с октября по март торфяная почва теплее, чем минеральная. Положительные разности температур в холодный период сохраняются на глубинах от 30 до 160 см, однако с увеличением глубины время начала регистрации положительных разностей сдвигается с октября на декабрь. Среднее значение разности температур торфяной и минеральной почв составляет около $1.1^{\circ} \mathrm{C}$, а максимальная величина $\left(2.1 \pm 0.8^{\circ} \mathrm{C}\right)$ регистрируется в ноябре на глубине $60 \mathrm{~cm}$.

На глубине 240 см отрицательные разности температуры между торфяной и минеральной почвой зафиксированы с июня по январь, с наименьшими значениями $-4.8 \pm 0.5^{\circ} \mathrm{C}$ в августе и сентябре. Как и в выше лежащих слоях в определенный период (с февраля по май) температура на этой глубине на болоте немного (до $+0.6 \pm 0.2^{\circ} \mathrm{C}$ ) выше, чем в минеральной почве (см. Рис. 4).

\section{3АKחЮЧEIIИE}

Анализ временного хода температур торфяной и минеральной почв за период с сентября 2011 г. по июль 2018 г. показал, что средняя многолетняя годовая температура почвы на болоте на $1.0-1.7^{\circ} \mathrm{C}$ ниже, чем минеральной. В целом, почва на болоте холоднее, чем на метеостанции, однако в годовом ходе разность температур почвы меняет свой знак. Отрицательные разности с величиной до $-4.1 \pm 1.2^{\circ} \mathrm{C}$ сохраняются до глубины 15 см в течение всего года. Начиная с глубины 20 см торфяная почва теплее, чем минеральная в течение холодного периода на $0.2-2.1^{\circ} \mathrm{C}$. В теплый период торфяная почва холоднее минеральной на $0.2-6.7^{\circ} \mathrm{C}$.

Таким образом, вследствие своего особого строения и насыщенности влагой торфяные почвы обладают особым температурным режимом. На границе уровня стояния болотных вод тепло эффективно поглощается в теплый период, расходуясь преимущественно на испарение. Вследствие чего, в торфяной почве в поверхностных слоях наблюдаются повышенные градиенты температуры, а рыхлые верхние слои мохового очеса из-за своей высокой теплоизолирующей способности существенно снижают температуру и амплитуду колебаний температуры в нижележащих слоях торфяной толщи. Зимой верхние слои торфяной почвы охлаждаются сильнее, чем в минеральной, однако температура в нижележащих насыщенных водой слоях выше и повышенная тепловая инерция торфяной толщи препятствует ее охлаждению, вследствие чего торфяная почва на глубине теплее минеральной.

Исследование выполнено при финансовой поддержке РФФИ в рамках научных проектов № 18-05-00306, 19-35-90027 и при поддержке средств гранта № 13-01-20/26 ЮГУ.

\section{СПИСОК ИСПОПЬЗОВАННОЙ ПИТЕРАТУРЫ}

1. Архангельская ТА, 2012. Температурный режим комплексного почвенного покрова. ГЕОС: Москва: 281 с.

2. Базаров АВ, Бадмаев НБ, Кураков СА, Гончиков Б-МН, 2018. Мобильный измерительный комплекс для сопряженного контроля атмосферных и почвенных параметров. Метеорология и гидрология. 4:104-109.

3. Базаров АВ, Бадмаев НБ, Кураков СА, Гончиков Б-МН, Цыбенов ЮБ, Куликов АИ, 2016. Измерительный комплекс для автоматического долговременного контроля атмосферных и почвенных климатических параметров. Приборы и техника эксперимента. 4:158-159. doi: 10.7868/S0032816216040182

4. Васильев АА, Дроздов ДС, Москаленко НГ, 2008. Динамика температуры многолетнемерзлых пород Западной Сибири в связи с изменениями климата. Криосфера Земли. 12:10-18.

5. Вомперский СЭ, Сирин АА, Цыганова ОП, Валяева НА, Майков ДА, 2005. Болота и заболоченные земли России: попытка анализа пространственного распределения и разнообразия. Известия Российской академии наук. Ceрия географическая. 5:39-50.

6. Воропай НН, Киселев МВ, Черкашина АА, 2019. Мониторинг температуры почв на многолетнемёрзлых породах 
в естественных и антропогенно нарушенных условиях Тункинской котловины. Лед и снег. 59:517-528.

7. Второй оценочный доклад Росгидромета об изменениях климата и их последствиях на территории Российской Федерации, 2014.

8. Ершов ЭД, ред, 1989. Геокриология СССР. Западная Сибирь. Недра, Москва: 454 с.

9. Гиличинский ДА, 1986. Сезонная криолитозона Западной Сибири. Наука, Москва: 143 с.

10. Головацкая ЕА, Дюкарев ЕА, Ипполитов ИИ, Кабанов МВ, 2008. Влияние ландшафтных и гидрометеорологических условий на эмиссию СО2 в торфоболотных экосистемах. Докл. РАН. 418:539-542.

11. Доктуровский ВС, 1932. Торсяные болота. Курс лекций по болотоведению. Государственное научно-техническое горное издательство, Москва-Ленинград: 192 с.

12. Дюкарев ЕА, 2015. Влияние температуры воздуха и снежного покрова на характеристики сезонно-мерзлого слоя почвогрунтов. Криосфера Земли. 19:45-51.

13. Дюкарев ЕА, Головацкая ЕА, 2013. Особенности температурного режима торфяной залежи олиготрофного болота в южной тайге Западной Сибири. География и природные ресурсы. 1:65-71.

14. Дюкарев ЕА, Головацкая ЕА, Дучков АД, Казанцев СА, 2009. Экспериментальное исследование температурного режима торсяной залежи Бакчарского болота (Западная Сибирь). Геология и геосизика. 50:745-754.

15. Иванов КЕ, Новиков СМ, 1976. Болота Западной Сибири, их строение и гидрологический режим. Гидрометеоиздат, Ленинград: 447 с.

16. Кабанов МВ, 2012. Исследование природно-климатических процессов на территории Большого Васюганского болота. Изд-во СО РАН, Новосибирск: 244 с.

17. Каверин ДА, Пастухов АВ, Панюков АН, 2019. Температурный режим почв постагрогенных экосистем при активизации самовосстановительной сукцессии тундровой растительности (Европейский северо-восток России). Криоссрера Земли. 23:58-66. doi: 10.21782/KZ15607496-2019-5(58-66)

18. Калюжный ИЛ, Батуев ВИ, 2015. Формирование температурного режима торфяной залежи при изменении климатических характеристик в северной и северо-западной зоне олиготрофных болот ЕТР. Труды Главной геофизической обсерватории им. А.И. Воейкова. 577:156-168.

19. Киселев МВ, Воропай НН, Дюкарев ЕА, 2016. Особенности температурного режима почв верхового болотного массива. Известия ВУЗов. Физика. 29:93-98.

20. Киселев MB, Воропай НH, Дюкарев ЕА, 2017. Температурный режим почвы осоково-сфагновой топи верхового болота в южной тайге Западной Сибири. География и природные ресурсы. 3:110-117.

21. Китаев ЛМ, Кислов АВ, 2008. Региональные различия снегонакопления - современные и будущие изменения. Криосфера Земли. 2:98-104.

22. Шишов ЛЛ, Тонконогов ВД, Лебедева ИИ, Герасимова МИ, 2004. Классификация и диагностика почв России. Ойкумена, Смоленск: 342 с.
23. Константинов ПЯ, Аргунов РН, Герасимов ЕЮ, Угаров ИС, 2006. О связи глубины сезонного протаивания с межгодовой изменчивостью средней годовой температуры грунтов. Криосфера Земли. 10:15-22.

24. Коронатова НГ, 2019. Температурный режим торфяных олиготрофных почв Бакчарского болота (Западная Сибирь). Почвы и окружающая среда. 2:1-13.

25. Коронатова НГ, Миронычева-Токарева НП, Соломин ЯР, 2018. Температурный режим торфяной залежи бугров и топей плоскобугристых болотных комплексов Западной Сибири. Криосфера Земли. 22:16-25. doi: 10.21782/ KZ1560-7496-2018-6(16-25)

26. Евсеева НС, Синюткина АА, Харанжевская ЮА, Войстинова ЕС, Ромашова ТВ, Хромых ВB, Земцов ВА, Сорокин ИБ, Гузова ЕН, Сиротина ЕА, Жилина ТН, Квасникова 3Н, 2012. Ландшафты болот Томской области. Изд-во НТЛ, Томск: 400 с.

27. Лисс ОЛ, Абрамова ЛИ, Аветов НА, Березина НА, Инишева ЛИ, Курнишкова ТВ, Слука ЗА, Толпышева ТЮ, Шведчикова НК, 2001. Болотные системы Западной Сибири и их природоохранное значение. Гриф и К०, Тула: 584 с.

28. Марчик ТП, Ефремов АЛ, 2006. Почвоведение с основами растениеводства. ГрГУ, Гродно: 249 с.

29. Махатков ИД, Ермолов ЮВ, 2015. Температурный режим деятельного слоя верхового болота северной тайги. Междунар. журн. прикл. и фундам. исслед. 11:400-407.

30. Беспалов ДП, ред, 1985. Наставление гидрометеорологическим станциям и постам. Вып. 3. Часть 1. Метеорологические наблюдения на станциях. Гидрометеоиздат, Ленинград: 58 с.

31. Ершов ЭД, ред, 2001. Основы геокриологии. Изд-во Московского. ун-та, Москва: 688 с.

32. Осокин НИ, Сосновский АВ, 2014. Пространственная и временная изменчивость толщины и плотности снежного покрова на территории России. Лед и снег. 128:72-80.

33. Павлов АВ, 2008. Мониторинг криолитозоны. Акад. издво «Гео», Новосибирск: 230 с. [Pavlov A, 2008. Monitoring Kriolitozony. Akad. izd-vo «Geo», Novosibirsk: 230 pp. (In Russian)].

34. Павлов AB, 1975. Теплообмен почвы с атмосфрерой в северных и умеренных широтах территории СССР. Якутск. Кн. Изд-во, Якутск: 302 с.

35. Романов ВВ, 1961. Гидрофизика болот. Гидрометеоиздат, Ленинград: 359 с.

36. Сергеев ДО, Ухова ЮА, Станиловская ЮВ, Романовский ВE, 2007. Температурный режим многолетнемерзлых толщ и сезонноталого слоя в горах Северного Забайкалья (Возобновление стационарных наблюдений). Криосфера Земли. 11:19-26.

37. Серебрянская ГА, 1946. Промерзание и оттаивание почвогрунтов в центральной части Барабы. Почвоведение. 9:555-564.

38. Трофимова ИЕ, Балыбина АС, 2015. Районирование Западно-Сибирской равнины по термическому режиму почв. География и природные ресурсы. 3:27-38.

39. Трофимова ИЕ, Шеховцов АИ, 2011. Оценка термического режима почв котловин Прибайкалья и Северного Забайкалья. География и природные ресурсы. 4:100-107. 
40. Харюткина EB, Логинов СВ, 2019. Тенденции временных изменений температуры почвы на глубинах в Западной Сибири по данным реанализа. География и природные ресурсы. 2:95-102. doi: 10.21782/GIPR0206-1619-20192(95-102)

41. Чечкин СА, 1970. Водно-тепловой режим неосушенных болот и его расчет. Гидрометеоиздат, Ленинград: 205 c.

42. Чигир ВГ, 1978. Тепловая мелиорация длительно-сезонномерзлых почв. Наука, Москва: 147 с.

43. Шерстюков АБ, 2008. Корреляция температуры почвогрунтов с температурой воздуха и высотой снежного покрова. Криоссера Земли. 12:79-87.

44. Шерстюков АБ, Шерстюков БГ, 2015. Пространственные особенности и новые тенденции в изменениях термического состояния почвогрунтов и глубины их сезонного протаивания в зоне многолетней мерзлоты. Метеорология и гидрология. 2:5-12.

45. Belyea LR, 2009. Non-linear dynamics of peatlands and potential feedbacks on the climate system, p. 5-18 In: Baird A, L Belyea, and X Comas (eds.), Northern Peatlands and Carbon Cycling, Washington: American Geophysical Union.

46. Stocker TF, Qin D, Plattner G-K, 2013. The Physical Science Basis. Contribution of Working Group I to the Fifth
Assessment Report of the Intergovernmental. Panel on Climate Change. Cambridge University Press, Cambridge: $1535 \mathrm{pp}$.

47. Kiselev MV, Voropay NN, Dyukarev EA, Kurakov SA, Kurakova PS, Makeev EA, 2018. Automatic meteorological measuring systems for microclimate monitoring. IOP Conference Series: Earth and Environmental Science. 190:012031.

48. Kiselev MV, Voropay NN, Dyukarev EA, Preis Yul, 2019. Temperature regimes of drained and natural peatlands in arid and water-logged years. IOP Conference Series: Earth and Environmental Science. 386:012029.

49. Peng X, Frauenfeld OW, Zhang T, Wang K, Cao B, Zhong X, Hang S, Mu C, 2017. Response of seasonal soil freeze depth to climate change across China. The Cryosphere. 11:10591073. doi: 10.5194/tc-2016-129

50. Rydin H, Jeglum H, 2015. The Biology of Peatlands. Oxford. Univ. Press, Oxford: $400 \mathrm{pp}$.

51. Zhong X, Zhang T, Kang S, Wang K, Zheng L, Hu Yu, Wang $H$, 2018. Spatiotemporal variability of snow depth across the Eurasian continent from 1966 to 2012. The Cryosphere 12:227-245. doi: 10.5194/tc-12-227-2018

Поступила в редакцию: 09.09.2019 Переработанный вариант: 11.10.2019 